\title{
Mariusz Chamarczuk SDB, Problematyka integracji imigrantów w Kościele katolickim w Szwecji (Studia i Rozprawy, 5), Towarzystwo Naukowe Franciszka Salezego. Warszawa 2013, 311 s.
}

Mariusz Chamarczuk podejmuje w swojej nowej książce interesujący i nadal słabo zbadany temat działalności pastoralnej Kościoła katolickiego w Szwecji, ze szczególnym zwróceniem uwagi na integrację katolików-imigrantów we wspólnotach katolickich orazw ramach różnych struktur kościelnych. Autor wiele lat pracował w Sztokholmie, gdzie pełnił funkcje duszpasterza w Polskiej Misji Katolickiej, diecezjalnego duszpasterza młodzieży, sędziego sądu biskupiego, dyrektora zgromadzenia salezjanów, rektora wielokulturowej wspólnoty katolickiej przy kościeleśw. Botvida w Fittji (okolice Sztokholmu). Jego praca ma charakter naukowy, nosi poza tym - z uwagi na długoletnie doświadczenie autora w pracy pastoralnej za granicą - cechy autentyczności.Jest to zdecydowanie duża zaleta tej rozprawy.
Książka Chamarczuka oprócz wprowadzenia metodologicznego obejmuje pięć obszernych rozdziałów. W pierwszych z nich autor wskazuje na zjawisko emigracji i imigracji we współczesnym świecie i przedstawia w zarysie dzieje Kościoła katolickiego w Szwecji. Zwraca przy tym szczególną uwagę na wydarzenia, które wpłynęły na jego status prawny i formy działalności w państwie szwedzkim. Analizuje wypowiedzi szwedzkich i skandynawskich biskupów na temat integracji, pisze o roli tzw. integracji wewnętrznej w samym Kościele, omawia szeroką działalność pastoralną, w tym pracę duszpasterską misji narodowo-językowych, np. Polskiej Misji Katolickiej prowadzonej od dziesięcioleci przez zgromadzenie salezjańskie. Charakteryzuje poza tym katolickie formy wychowania 
i kształcenia od żłobków i przedszkoli począwszy, a na uniwersytetach ludowych oraz otwartym w roku $2001 \mathrm{w}$ Uppsali Instytucie Newmana (Wyższa Szkoła Teologii, Filozofii i Kultury) skończywszy.

W kolejnych częściach pracy Chamarczuk opisuje i analizuje struktury administracji Kościoła katolickiego w Szwecji na poziomie diecezjalnym i parafialnym oraz różne formy integracji imigrantów w przestrzeni religijno-kulturowo-socjalnej. Sporo miejsca poświęca przy tym ruchowi ekumenicznemu i dialogowi międzyreligijnemu. Tutaj też koncentruje się na pracy charytatywnej Kościoła oraz na działalności katolickich związków i stowarzyszeń kulturowych.

W rozdziale przedostatnim, który różni się pod względem metodologicznym od historyczno-kulturowej części rozprawy, autor sięga do metod socjologicznych. Na postawie badań ankietowych, jakie przeprowadził w kilku parafiach, stara się ustalić, w jaki sposób przybysze-imigranci postrzegają pracę pastoralną Kościoła oraz życie wspólnot katolickich w Szwecji. Informatorami są tutaj katolicy pochodzący z różnych stron świata, ludzie o odmiennych korzeniach kulturowych, osoby porozumiewające się różnymi językami. Zaangażowanie wiernych w działalność religijną i przykościelną jawi się czytelnikowi jako problem niełatwy do uchwycenia, złożony, dynamiczny, zmienny w czasie.

Mariusz Chamarczuk uwzględnia w swojej książce bogate materiały źródłowe, ustosunkowuje się do szwedzkich prac nawiązujących w pewien sposób do tematu rozprawy, zaopatrza książkę w tabele i wykazy, które ukonkretniają prowadzony w książce wywód naukowy. Z uwagi na wieloaspektowość podejmowanej problematyki autor stosuje w pracy różne metody badań. Czerpie je przede wszystkim z historii i kultury, ale też z socjologii, co sprawia, że penetrowany w ten sposób problem integracji imigrantów w działalności Kościoła ukazywany jest z różnych perspektyw. Rozprawa zawiera bogatą bibliografię, która obejmuje materiały drukowane, internetowe i archiwalne.

Książka Chamarczuka jest zdecydowanie ważną pozycją o dziejach i pracy duszpasterskiej Kościoła katolickiego za granicą. Podjęta w niej tematyka jest bardzo aktualna we współczesnym świecie. Co prawda dotyczy Szwecji, ale odnosi się również do działalności Kościoła katolickiego w innych krajach, w których emigranci-katolicy znajdują nowe miejsce zamieszkania i w których mają możliwość zachowania i praktykowania swojej wiary. Chamarczuk podkreśla ważny, często jednak niedostrzegany lub pomijany wymiar działalności pastoralnej Kościoła katolickiego za granicą i pisze: „Należy [...] pamiętać, iż Kościół katolicki poprzez integrację imigrantów wypełnia także rolę państwowotwórczą, ponieważ imigranci ucząc się obecności w szwedzkojęzycznym środowisku katolickim, uczą się także i poznają kulturę, język i sposoby zachowań obecne w szwedzkim społeczeństwie. Stają się przez to uczestnikami życia społecznego i państwowego" (s. 251).

Rozprawa Problematyka integracji imigrantów w Kościele katolickim w Szwecji otwiera drogę do dalszych badań nad statusem, rolą i formami pracy Kościoła katolickiego w Szwecji (i nie tylko tam), Kościoła, który z niewielkiego, przez wieki niemal „zakazanego" i marginalizowanego, stał się w ostatnich dziesięcioleciach największym po Kościele szwedzkim (Svenska kyrkan) Kościołem chrześcijańskim w laickim, zsekularyzowanym, wieloetnicznym i wielokulturowym społeczeństwie Królestwa Szwecji.

Ewa Teodorowicz-Hellman 